\title{
ПРОИЗВОДСТВО
}

\section{"ЭЛЕКТРОПРОВОД": праздник особого значения}

л.Павлова

DOI: 10.22184/2070-8963.2021.98.6.34.37

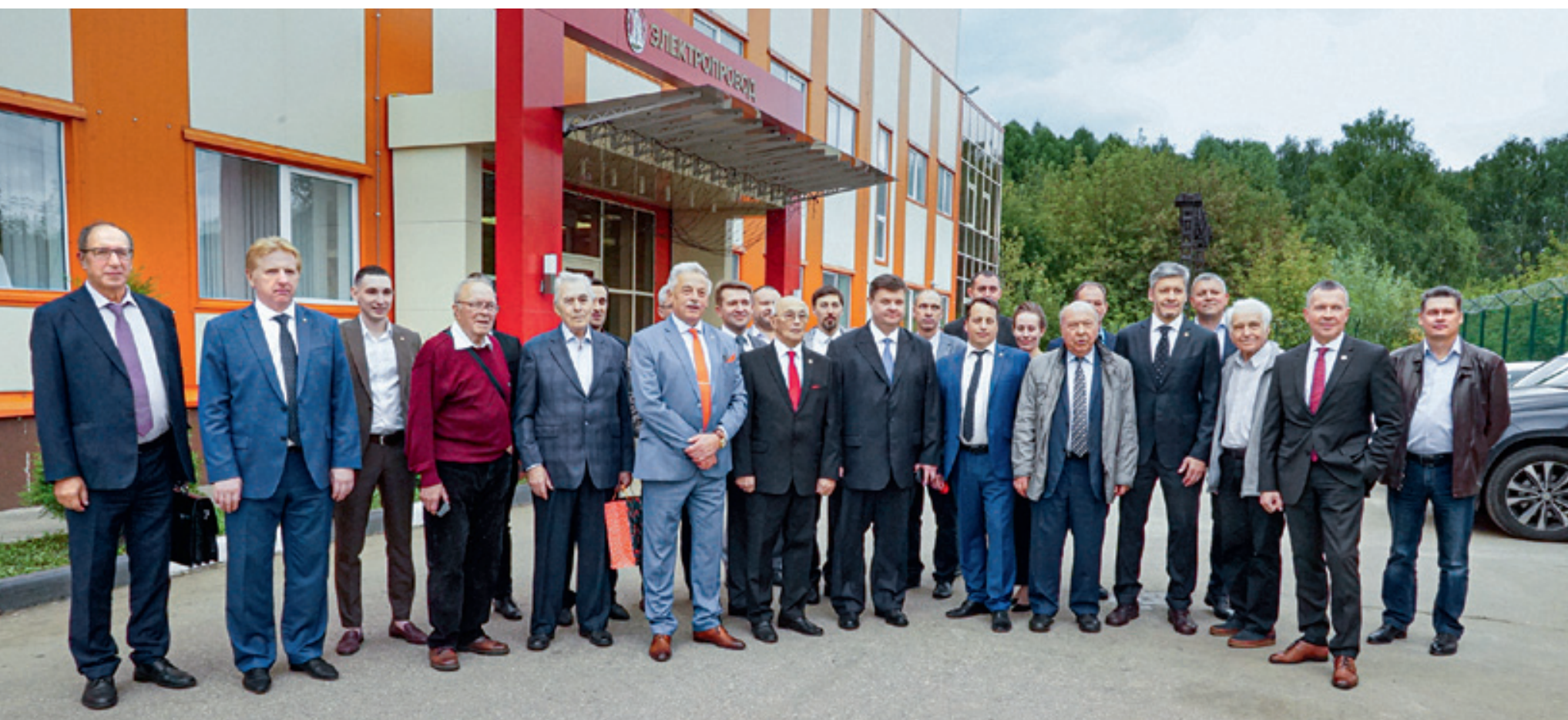

Любое упоминание об этом заводе неизбежно сочетается с определением "особый". Здесь все особое - его истоки, продукция и, конечно же, его люди, создающие особую атмосферу коллективной жизни. Даже, казалось бы, проходное по меркам 236-летней истории завода мероприятие, посвященное завершению строительства здания второго производственного корпуса завода, приуроченное к 10-летию начала строительства первого цеха здесь же, в г. Подольск Московской области, стало особой вехой жизни этого уникального предприятия.

ОСОБОЕ ПРОИСХОЖДЕНИЕ

Завод "Электропровод" ведет свою историю с 1785 года, когда купец II гильдии Семен Алексеев основал в Москве фабрику волочения золота и серебра. В период с 1892 по 1917 год заводом руководил всемирно известный театральный деятель, актер и режиссер К.С.Станиславский - правнук Семена Алексеева (Станиславский - псевдоним К.С.Алексеева). Именно благодаря уму, энергии и организаторским 
способностям К.С.Станиславского заводы товарищества "Владимир Алексеев" и "П.Вишняков и А.Шамшин", преобразованные впоследствии в "Электропровод", ко времени Октябрьской революции в 1917 году представляли собой мощное электротехническое предприятие, оснащенное наиболее современными в то время машинами и оборудованием и стоявшее на одном из первых мест среди родственных кабельных заводов России. Кабельный корпус завода, построенный под руководством К.С.Станиславского на ул. Малая Алексеевская, д. 21 (в настоящее время - ул. Станиславского), до 2003 года был главным производственным корпусом завода Народная Фирма "Электропровод" (НФ "Электропровод"). На этом заводе разрабатывали первые в Советском Союзе полиэтилены и пластикаты, отрабатывалась технология изготовления радиочастотных кабелей, а в 1981 году были изготовлены первые метры оптического кабеля (OK) в СССР и в дальнейшем освоено его промышленное производство.

В своей новейшей истории "Электропровод" пережил немалые потрясения: рейдерские захваты в 90-х; перевод и запуск производства в г. Ивантеевка Московской области в начале 2000-х; очередной переезд в 2011-м году, теперь уже в "самый кабельный" город Подмосковья - Подольск.

Как это произошло? Учитывая славную историю завода, его традиции и значимость в кабельной промышленности страны, руководство ЗАО "Торговый Дом ВНИИКП", найдя финансирование, приняло решение о покупке земли и строительстве нового корпуса завода площадью 10000 м в г. Подольске, рядом с тем местом, где в 1915 году Товарищество "Владимир Алексеев" и "П.Вишняков и А.Шамшин" начало строительство нового современного завода большой мощности во исполнение заказа Главного военно-технического управления.
Это непростое решение в годы кризиса 2009-2011 годов приняли Е.Б.Васильев, генеральный директор ЗАО "Торговый Дом ВНИИКП", Г.И.Мещанов, генеральный директор ОАО "ВНИИКП", и И.Б.Пешков, председатель Совета директоров ОАО "ВНИИКП".

\section{Осовое место}

Подольск - традиционный центр электротехнической и кабельной промышленности. "Подольск называют столицей кабельной промышленности, - отмечает Изяслав Пешков, президент ассоциации "Интеркабель". - Время идет, где-то объемы промышленности уменьшаются, но Подольск остается одним из крупнейших центров. Здесь сосредоточено не только производство кабелей и проводов, но и разработки новых материалов и новой кабельной продукции, тут крупнейший в Европе испытательный центр".

Итак, ровно 10 лет назад совет директоров завода принял решение обосноваться в Подольске. Строительство начали в сентябре, а уже в феврале 2011 года запустили оборудование. Первый камень в производственный корпус завода "Электропровод" заложили в сентябре 2011 года - и уже в 2012 году завод снова начал свою работу, теперь уже на абсолютно новой, специально построенной под самые современные нужды производства, площадке.

В настоящее время это действующее предприятие, уникальная продукция которого служит интересам обороны, безопасности, развития энергетики, транспорта и многих других отраслей жизнедеятельности страны.

\section{ОСОБОЕ НАЗНАЧЕНИЕ}

В настоящее время "Электропровод" выпускает более трех тысяч видов продукции (волоконнооптические кабели (ВОК), провода и кабели

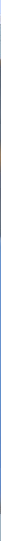


с использованием кремнийорганической резины и др.) для спецзаказчиков, таких как РЖД, Метрополитен, Росавиация, Роскосмос. Кроме того, это единственный в России производи тель оптических кабелей для атомных электростанций. "Сегодня „Электропровод” - это, прежде всего, предприятие, которое работает в зоне специальных видов техники, - отмечает Евгений Васильев, председатель совета директоров завода. - Оно не занимается простыми изделиями. Это сложнейшие кабельные изде лия, которые идут для Минобороны, для ВМФ".

Кстати, новые виды продукции здесь начнут осваивать и благодаря открытию второй очереди завода. Строительство объекта уже закон чено, осталось только получить заключение о соответствии.

\section{ОСОБЫЙ ПРАЗДНИК}

Итак, в сентябре этого года на территории "Электропровода", который глава округа Николай Пестов назвал площадкой, "проверенной временем и трудом поколений", завершено строительство второго производствен ного корпуса. Поздравляя заводчан с особо важным событием, он отметил: "Десять лет назад было заложено производство. Они пролетели, и сегодня мы осмотрели и построенный новый корпус, который в ближайшее время начнет работу. Мне очень приятно, что лучшие традиции отечественной кабельной промышленности продолжают не просто жить, а на экономическую отдачу работать, в том числе на подольской земле. Сегодня мы смогли познакомиться с уникальным производством. Несколько лет назад здесь не все было завершено, а сейчас весь спектр изделий служит интересам обороны, безопасности и хозяйственным нуждам страны. Признателен коллективу, который идет вперед, и новые рабочие места создаются, и новое производство осваивается. Значит, кабельная промышленность Подольска продолжает свое развитие".

Уже в 2022-м году новый корпус заработает в полную силу, а объемы производства увеличатся в два раза.

\section{ОСОБЫЙ ГЕНЕТИЧЕСКИЙ КОД}

Лучшие традиции "Алексеевского кабельного завода" и сегодня сильны в коллективе завода "Электропровод", базирующегося в г. Подольск на Бронницкой ул., д. 13.

Рабочие завода обеспечены отличными бытовыми помещениями с индивидуальными шкафами, оборудованными сантехническими устройствами и душевыми кабинами. На заводе функционирует прекрасный зал столовой (при этом дирекция завода дотирует 50\% закупаемых продуктов). Сегодня завод не имеет своих социальных объектов (детского сада, оздоровительного лагеря), как и многие другие промышленные предприятия, так как в 90-е годы в период развала экономики страны многие социальные объекты были переданы муниципальным органам власти или скуплены "дельцами" за бесценок. После этого практически все они прекратили существование. Тем не менее, в настоящее время на заводе регулярно проводятся спортивные соревнования по футболу и волейболу в своем коллективе, а также соревнования между предприятиями, входящими в холдинг "Торгового Дома ВНИИКП".

Сильны и театральные традиции. Заводчане вместе с сотрудниками "Торгового Дома ВНИИкП" ежегодно к Новому году ставят спектакли по собственным сценариям, снимают любительские фильмы, участвуют и способствуют работе бард-клуба авторской песни, где встречаются и поют свои песни известные барды страны.

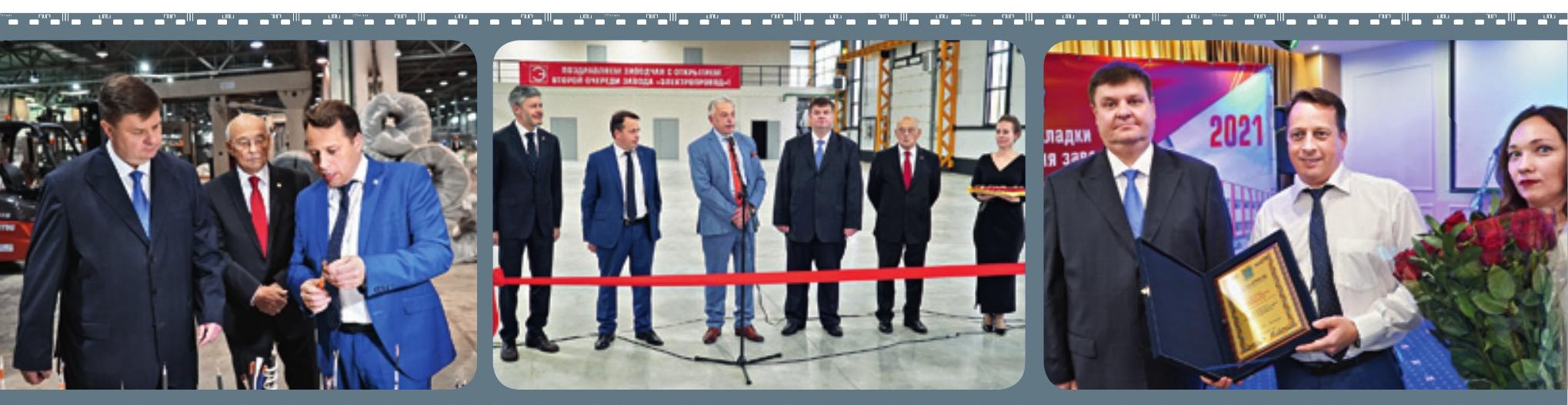

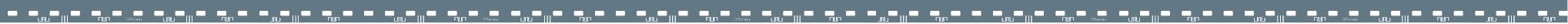


Хранит традиции и обеспечивает новаторство молодой и энергичный коллектив, обладающий опытом и профессиональными знаниями, сформированный в последние пять-шесть лет. С ноября 2016 года завод возглавил к.т.н. Роман Евгеньевич Васильев, став генеральным директором. Главным инженером с 2015 года работает А.А.Акимов, коммерческим директором с 2016 года - М.В.Дуйнов (ранее возглавлял завод в 2009-2016 г.), директором по качеству с 2014 года - И.Г.Калюжная. Цех медных кабелей возглавляет К.В.Киреев, цех оптических кабелей - И.В.Рыбаков. Надо отметить, что, несмотря на огромные трудности, которые сотрясали завод в начале двухтысячных годов, сегодня на заводе по-прежнему трудятся ветераны, работавшие еще на Таганке. Это К.В.Киреев, И.В.Пономарев, Н.Ю.Кирилин, В.С.Мочалин, Ю.А.Загороднев, И.Н.Климова, Р.Е.Васильев, В.И.Дощицина.

Такой сплав молодости и опыта за три года позволил поднять производство в три раза, освоить десятки типов новых проводов и кабелей, разработать серию кабельной продукции для нужд Министерства обороны РФ, космоса, атомных станций, морского флота и других отраслей народного хозяйства.
Как и при Станиславском, здесь правят бал ум, энергия и организаторские способности руководства завода. И преданность профессии. В наше время универсальных топ-менеджеров, свободно перемещающихся по отраслевым вертикалям с главной задачей формирования финансовых потоков, золотым фондом объединения кабельщиков остаются мастера своего дела. Ну где еще мы встретим сегодня структуру, в которой молодых полевых командиров направляет совет старейшин (в нашем случае это основанный учредителями "Электропровода" Совет ветеранов)?! Логично, что празднование завершения очередного этапа строительства завода не могло обойтись без чествования патриарха и легенды кабельной промышленности Виктора Семеновича Берсона, которому в нынешнем году исполнилось 90 лет. Поздравления и памятные подарки получили в этот день и другие работники завода, никто не остался обойден вниманием. С праздником, заводчане!

В статье использованы материалы книги Е.Б.Васильева "На рубеже тысячелетий. История завода "Электропровод" (к 235-летию со дня основания)". М.: Издательство "Торговый дом ВНИИКП", 2020.

\section{Состоялось ежегодное Общее собрание Ассоциации "Электрокабель"}

С 13 по 16 сентября в Завидово (Тверская область) в очном режимепрошло 78 Общее собрание членов Ассоциации "Электрокабель" (АЭК), которой исполнилось в текущем году 30 лет. Ассоциация объединяет существенную долю предприятий кабельной промышленности РФ и стран СНГ - до 75\% рынка.

В собрании приняли участие более 120 делегатов из 60 компаний.

Среди главных итогов события отмечаются:

- была представлена обновленная версия декларации качества по применению ново- го ГОСТ на поливинилхлорид LS в кабельных изделиях. Большинство членов АЭК готовы подписать документ;

- в состав Ассоциации принято шесть новых членов;

- приняты изменения в устав АЭК. Взносы будут взиматься в зависимости от оборота компании, а все постоянные участники Ассоциации получают право голоса;

- приоритетом признан экспорт, однако готового плана реализации представлено не было.
АЭК продолжит инициативы по поддержке экспорта и, в первую очередь, решение задач по международной сертификации отечественной продүкции;

- инициированы вопросы разработки и обновления ГОСТов на кабельную продукцию, введенных ранее 1992 года, которые будут "отрезаны" регуляторной гильотиной.

По информации НП "Ассоциация "Электрокабель"

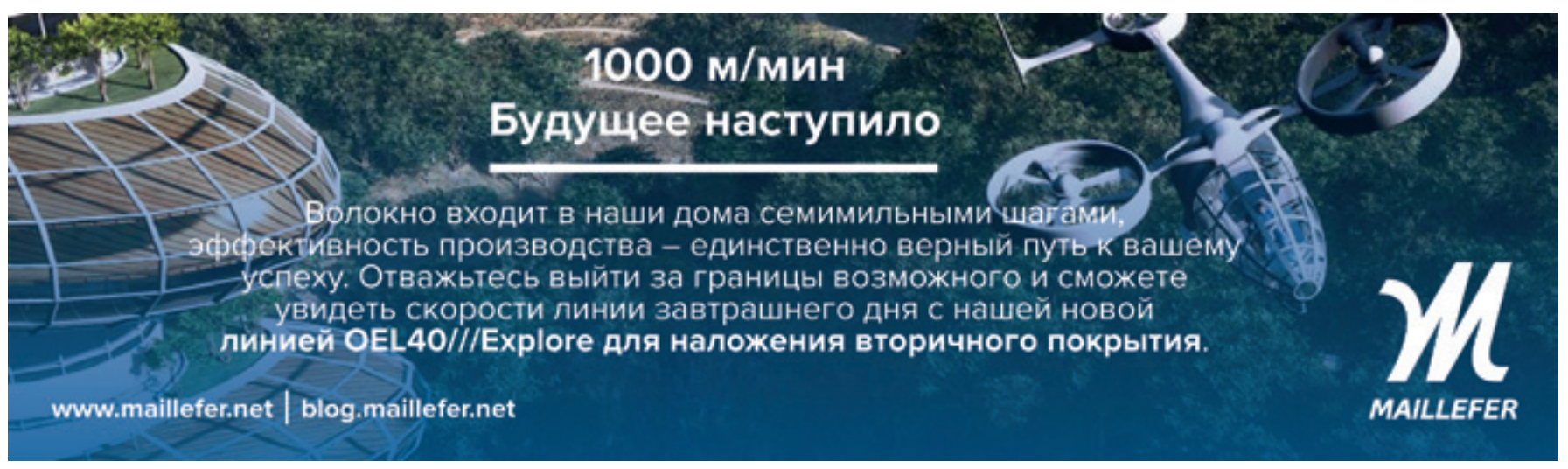

